\title{
Adult education in two public libraries in Cape Town: a case study
}

\author{
Mary Nassimbeni ${ }^{1}$ \\ Centre for Information Literacy/Department of Information and Library Studies, \\ University of Cape Town
}

and

\author{
Nobubele Tandwa ${ }^{2}$ \\ Librarian, Cape Town City Libraries
}

\begin{abstract}
Received: $20^{\text {th }}$ July 2007
Accepted: $17^{\text {th }}$ April 2008

This paper reports the findings of research (Tandwa 2007) into adult literacy programmes offered by two public libraries in Cape Town with a focus on their use of literacy materials. The study is a contribution to the documenting and analysis of the public library's role in the struggle against illiteracy, a serious socio-economic problem in South Africa. Using the case study approach the researcher made an in-depth study of the programme offerings from the perspective of the adult learners, and tried to establish how and whether they made use of literacy materials, since their availability is so important in literacy instruction and the development of a reading habit. The paper describes the programmes and the cohorts of learners and their expectations, and analyses the availability and role of reading materials in the learners' lives. It concludes by identifying the factors required for the successful implementation of a literacy programme in a public library.
\end{abstract}

Keywords: adult education, public libraries, South Africa, literacy materials, literacy programmes

\section{Introduction}

Illiteracy is viewed as a socio-economic problem and an obstacle to development that affects the economy and the individual's life because it is linked to unemployment, poor health, diseases, high birth rates, poverty, dependency on social grants and crime. Literacy does not only equip adults with employment skills but also with developmental skills to engage with health related issues like nutrition, a healthy life-style and children's education and also the ability to participate fully in democracy (Foulk et al. 200 I; Roman 2004; Zapata 2004).

The United Nations Educational, Scientific and Cultural Organisation (UNESCO) report (2005: 137) indicates that

'literacy goes beyond reading and writing because it provides access to the scientific and technical knowledge, legal information, cultural benefits and the ability to use and understand the media because it has a potential to meet peoples' most vital needs and to stimulate social, political, cultural and economic participation'.

Based on several definitions of literacy, a literate person is an individual who is able to do one of the following:

- Able to read and write a simple sentence

- Able to pass a written test of reading comprehension at basic level

- Able to engage in the majority of activities in which literacy is required for effective functioning in his/her community (this can include to ability to read road signs, filling in employment forms, voting, helping children with school work) (Pather 1995; Wagner 200I; UNESCO 2005).

The provision of literacy education entails various processes and transitional stages such as the following:

- from illiteracy to literacy (this stage is attained through the provision of literacy classes and the use of instructional and learning literacy materials in literacy centres)

- development and maintenance of literacy skills (post literacy programmes)

- independent learning (through regular access and usage of literacy materials) (Rogers 1994).

These three stages are supported by the availability of and access to relevant and suitable literary reading materials. An important and common way of supporting adult education programmes by public libraries is the provision of reading materials.

I. Mary Nassimbeni is an associate professor in the Centre for Information Literacy/Department of Information and Library Studies, University of Cape Town

2. Nobubele Tnadwa, author to whom correspondence should be sent, has an M Bibl degree from the University of Cape Town, awarded in June 2007. She is currently employed by Cape Town City Libraries. Nobubele.Tandwa@capetown.gov.za 


\section{The investigation}

The aim of the study was to investigate the role of reading materials in adult education programmes and their availability and use in two public libraries in Cape Town. The research questions of the study were as follows:

- How available are locally produced literacy materials for use in literacy programmes in public libraries?

- What are the types and features of these literacy materials?

- How suitable are the literacy materials in the adult learners' acquisition of literacy?

By working with two public libraries, the researcher hoped to gain an in-depth understanding of literacy materials in adult education and the need for the provision of these materials in public libraries to support reading and adult literacy programmes. The intention was also to establish how and whether the literacy materials have an impact on fighting illiteracy and changing the lives of the illiterates.

Since the experience of the adult learners was of key concern, qualitative research methods were viewed as suitable for this investigation. Two public libraries currently offering literacy programmes in Cape Town were selected as cases. One of these libraries had two sites: the library and one at a local hospital where classes were offered to employees. Participants from these two literacy programmes were interviewed.

Respondents at each of the three sites were:

- Adult learners

- Facilitators

- Librarians

Data were collected through the use of face-to-face interviews, and observation. The researcher attended literacy classes twice a week over a six-month period. During this time she also examined the literacy material collections.

\section{Literature review}

The literature review frames the study conceptually highlighting the following related aspects:

- An examination of the meanings of literacy/illiteracy

- Purpose of adult education programmes

- Role of reading material in adult education programmes

- Adult education in South Africa

- Public libraries and adult education in South Africa

\subsection{Literacy/llliteracy}

Defining literacy is very difficult because it is associated with the use of a variety of skills such as reading, writing and calculation at different levels and for different purposes. Literacy is also influenced by the country's official language, that is one can be literate in his/her country's language and illiterate in another country because of the differences in official languages. The term literacy is also associated with the 'know how skills' and the use of those skills to improve one's life. Literacy is a major determinant factor of an individual's economic potential because literacy leads to higher employment participation, higher skilled employment, greater mobility and lower unemployment probabilities (Zapata 1994). Literacy is associated with the wealth of the country because the higher levels of education/literacy lead to greater productivity, and greater economic growth (Liu 2004). Generally illiteracy is associated with unequal access to resources, social wealth, information and knowledge (Zapata 1994). According to a UNESCO report (2005: 30) 'literacy strengthens the capabilities of individuals, families, and communities to access health, educational, political, economic and cultural opportunities and services'. Although literacy has several benefits, such benefits are not automatic but need to be exercised. This means that literacy strategies need to be delivered in such a way that they allow the illiterates to change their lives.

Illiteracy rates vary from one region to another but there are countries, especially in the developing world, that have notably high illiteracy rates. UNESCO reports that in 2000

'there were about 862 million illiterates in the world. In countries like India and Pakistan illiteracy rates are increasing. The majority of the illiterates are in Sub Saharan Africa, South and East Asia and Arab states' (UNESCO 2004).

\subsection{Adult education programmes}

There is little conceptual clarity about the meaning and use of terms like illiteracy, literacy, adult education and adult basic education. This difficulty is also found in measurement so that statistics are not easily comparable (Aitchison, 2006). The difficulty is compounded when trying to understand the relationship between a literacy programme and adult basic education. Aitchison argues that literacy programmes teach reading, writing and numeracy skills, whereas adult basic education provides more than the fundamental skills of literacy but offers the equivalent of a primary school education (2006). Torres's view of adult education shaped by her experience in the developing world is useful. She defines 'adult 
basic education as a foundation or essential education that aims at meeting and expanding the basic learning needs of adults' (2002: 21 ). She differentiates adult basic education from adult education saying that adult education is a broad term that entails basic and continuing education, vocational, technical higher education and professional development while adult basic education is basic or foundation education that enables the adults to grow and meet their daily needs (Torres 2002).

According to Harley et al. (1996) general aims of literacy programmes include the following:

- To enable adults to function properly without depending on others and to cope with written materials

- To enable people to cope with modernisation such as the ability to read urban road signs and the ability to cope with technological developments.

- The development of critical awareness ('conscientisation'). Critical awareness is specifically important for political participation because it enables the adults to be aware of structures that oppress them as a society. This is exemplified in programmes influenced by Paulo Freire.

- Competence (know-how skills). The provision of literacy classes enables the adults to deal with written materials and skills such as the ability to sign one's name, fill employment forms and to use ATMs.

- Development. Literacy enables increased productivity, improved health, fertility and gender issues, access to better jobs and environmental protection and economic growth (Harley et al. 1996).

Post literacy programmes differ in their areas of interest but their general aim is to develop, maintain, reinforce and sustain literacy skills through the provision of reading materials. Post literacy initiatives include any reading related programmes such as family literacy and book clubs that aim to fight illiteracy through the provision of reading materials.

\subsection{Literacy materials}

Various authors have used different terms to refer to literacy and post literacy materials. These terms include the following:

- 'Easy readers or Easy-to read materials include all the materials with text that is easy to read and understand not only because difficult words are avoided but because the presentation is specific and easy to follow' (Tronbacke 1997: 189).

- French (1992: 240) uses the term 'easy reading materials' to refer 'to any reading matter in any language which makes concessions to a lack of proficiency in reading skills or difficulties with mastering the language of the text'.

- Arnold (1982: 12) uses the term 'bridge literature' to refer to reading materials that act as a bridge between initial and habitual reading. Arnold further identifies various aims of the bridge literature such as developing the neo-literates' reading abilities so that they become habitual readers and improve their reading and writing abilities. For them to move successfully from being initial readers to habitual readers they need access to relevant and suitable reading materials (Arnold 1982).

All these terms are used to describe materials that have special characteristics and features for a particular purpose that differentiate them from any other reading materials. They can be categorised as:

- Curriculum materials including guides and workbooks used in classes by teachers and learners

- Reading materials used to practise and sustain literacy skills

The defining features of both reading and instructional materials are that the content, format and layout are adapted for easy comprehension by adults with limited reading skills (Tronbacke 1997). Most materials take the form of booklets and pamphlets but some producers also produce posters, newspapers, comic books, graphic novels and newspaper supplements.

The following features characterise literacy reading materials (reading and instructional materials) that are used in literacy classes, post literacy programmes and public libraries:

- Local, simple language and simple vocabulary (Tronbacke 1997).

- Simple syntactic structures (Sinha 1998).

- Importance of pictures (Tronbacke 1997; Reghu n.d; Sinha 1998, Thumbadoo 2006).

- Size of book, font size. number of pages, and number of sentences and paragraphs (Thumbadoo, 2006).

The relevance and suitability are determined by the needs, culture and the situation of the particular audience (Thumbadoo 2006). The content areas of these materials should offer a wide range of choices to accommodate different needs, interests, background and expectations of the intended audience. Although these books should be simple and relevant with illustrations and pictures, they should not be childish because they are to be used by mature adults with adult emotions and experience (Wedgeworth 2003). Tronbacke stresses the importance of the desirable attributes of literacy materials necessary "to provide a positive experience and to encourage adult to read them" (I997). It is important therefore for publishers, literacy providers and any other party involved in the production of these materials to make sure that they meet the needs of the semi-literates when writing and providing literacy materials (Land 2006).

SA Jnl Libs \& Info Sci 2008, 74(I) 
Literacy materials are published at different levels to accommodate the varying levels of their readers. These levels start from when an adult joins literacy classes to graduation and post literacy. They all serve different purposes for different learners. Within these levels they should also accommodate learners with disabilities (Tronbacke 1997).

\subsection{Adult education in South Africa}

In South Africa literacy education is subsumed into Adult Basic Education and Training (ABET) which is regarded as a basic human right in the South African Constitution necessary as a foundation for work, training and career progression and an educated workforce that is required for a prosperous democratic society (Aitchison 2006). The government's approach has been criticised by a number of researchers as being instrumentalist tied as it is to narrow goals of productivity and a path to employment (cf Baatjes and Mathe, 2004). ABET is provided by various organizations such as Non Governmental Organizations (NGOs), Government departments, business, industry and (on a minor scale) by public libraries. Rule (2005: 19) notes the great need for adult education provision in South Africa:

'adult education in South Africa is essential because it is an important mechanism for poverty alleviation and economic development, essential contribution to personal and community development, as a component for a democratic citizenship and civic participation and as a response to the historical legacy of apartheid deprivation'.

Ten million adults ( $50 \%$ of the South African adult population) have fewer than ten years' education, while three million have never been to school (Baatjes, 2003: 19I). Following the 1996 Census, the 200I Census showed that there had been a $50 \%$ increase in the number of adults never having gone to school (Baatjes 2003). These figures give an indication of the scale and scope of the problem which requires much more vigorous and sustained intervention by the government than has been evident in the last decade. Baatjes (2003), Baatjes and Mathe (2004) and Aitchison (2006) have documented and analysed government policies, plans and programmes and have shown that the government is unlikely to achieve the goal set by the Dakar Framework for Action which requires a reduction by $50 \%$ of adult illiteracy by 2015 . Nearly 10 million adults have such poor literacy skills that they are unemployable (Baatjes and Mathe 2004: 4I5) while those with fewer than nine year's schooling in the mining sector are most vulnerable to retrenchment (Baatjes and Mathe 2004: 410).

A number of commentators have analysed the problems of adult literacy programmes as follows:

- The lack of political will and commitment from the government (Baatjes 2003; Sibiya 2005). Rule (2005) states that in South Africa the provision of adult education is regarded as a basic human right but the government neglects it and it operates on a limited budget that is less than $1 \%$ of the total education budget.

- Limited budget for adult education provision and in some provinces such as KwaZulu-Natal it has gone to below than that of the apartheid era (Aitchison 1999). Vivian (2002: 16) notes that the funding is a major concern in adult education provision and the available NGOs' funding is very limited.

- NGOs have experienced problems such as funding uncertainties, loss of experienced staff and poor management (after 1997); some of these problems resulted in the collapse of the National Literacy Cooperation, USWE and English Literacy Project in 1998 (Aitchison 1999; 2006 and Rule 2005).

- The provision of ABET is also limited as the majority of government departments such as Department of Labour concentrate on their employees for skills development. This means that the majority of unemployed illiterates have limited access to literacy programmes (Rule 2005; Aitchison 2006).

Land and Buthelezi (2004: 429) argue that there is a limited number of suitable literacy materials and ABET materials especially materials in indigenous languages for various reasons such as poor sales, reluctance to publish in African languages, high illiteracy rates and lack of government support in promoting publishing of Indigenous materials. However various organisations such as Pan South African Language Board (PANSALB) are involved in promoting the publishing of literacy materials in various ways (Land and Buthelezi 2004).

\subsection{Public libraries and adult education in South Africa}

Harley (1999: 29) notes that libraries and literacy are inseparable because without the literate community the library is not likely to have an impact in the community and it is also difficult or even impossible to maintain literacy skills especially the newly acquired literacy skills without the library as a provider of the literacy materials or information in general. Reading is the basis of library use and it is therefore the role of the library to create readers.

Public libraries in South Africa are involved literacy in various ways such as the following:

- The provision of literacy materials (both reading and instructional materials) such as manuals and workbooks for learners and tutors/ facilitators, fiction and non-fiction biographies, magazines and newspapers for adults with limited reading skills (Frylinck 1984; Makhubela 1998; Harley 1999).

- Providing facilities such as venues and resources for the literacy classes (Frylinck 1984; Harley I999; May and Nassimbeni 2005). 
- Running literacy classes (Harley 1999; Makhubela 1998; May and Nassimbeni 2005).

- Promoting literacy and recruiting the illiterates (Harley 1999).

- Promoting the creation of literacy materials by working with publishers and writers (Frylinck 1984).

The scale of their involvement is rather modest as revealed by a national survey by May and Nassimbeni (2005: 12) showing that only $26.7 \%$ of South African public libraries are engaged in any way either through direct intervention and delivery of adult education programmes, or more usually through the provision of venue or materials. Most public libraries in South Africa do not have literacy materials and some public libraries do not know the publishers of these materials or where to find them (May and Nassimbeni 2005).

"Ours is not a society of readers" (Jordan, 2007). This is the observation of Minister of Arts and Culture during his budget speech to Parliament shortly before the launch of the report of the National survey into reading and book reading behaviour of adult South Africans (South African Book Development Council 2007). The report revealed that 5 I \% of South Africans have no books in their homes, and that only $14 \%$ read books. The extra funding to be released by the Department of Arts and Culture (RIbn announced in 2006; and a further R200m made available in 2007) has taken into account the need for special interventions to remedy the weak reading culture (RIbn boost for libraries 2006; Jordan 2007).

Sisulu (2004) identifies the following characteristics of the literate nation and nation with a reading culture:

- Nation with life-long readers who value their local literature

- Nation with government that promotes the value of reading at all levels

- Nation that integrates reading with education systems at all level and encourages reading for pleasure

- Nation with flourishing writing and publishing industry

- Strong library services backed with rich distribution of books from the book market.

\section{Research methodology}

Two public libraries, Library A and Library B were selected as cases. A case study approach was used because it is a qualitative research approach suitable for a study of social process (Miller and Salkind 2002) and it provides an ability to examine the real issues in their natural setting (Bogdan 1992). These sites were selected because they were involved in literacy programmes and they had literacy materials to support and maintain literacy programmes. The learners' behaviour and reactions in literacy classes and towards literacy materials were observed through attending the classes and interacting with the participants. Data and field notes were sorted according to the participants' categories, that is, learners, facilitators and librarians. Within these categories data was sorted according to themes and topics. Data was analyzed through physical sorting of field notes, reading and screening them for accuracy and double checking incomplete and unclear sections. Comparisons, insights and contrasts were made to facilitate the interpretation and analysis.

\section{Findings}

In this section we report the findings of the investigation following a brief description of the sites of study. Library $\mathrm{A}$ is in a relatively affluent middle class predominantly 'white' suburb with a very large informal settlement on its margins, and Library B is in a lower income predominantly 'coloured' suburb. Respondents were made up as follows:

- 54 adult learners

- Library A: 35

- Library B: 10 from the library and 9 from the hospital

- 2 librarians: one from each of the libraries

- Facilitators at each of the sites

5.1 The learners: their motives and expectations

In Library A, the principal motivation of the learners, drawn mainly from immigrants from other African countries wishing to learn English, was to enter the labour market from which they were excluded because of their poor English communication skills. They wished to improve their basic English in order to improve their lives, get jobs and solve their daily problems caused by their illiteracy. They indicated that their major problems were the inability to communicate and understand written information in English with the result that they were unable to get jobs, to express themselves in English and to read signs. The majority of learners were foreigners, literate in their home language, who viewed literacy in English as a prerequisite for functionality at work and within the family and the community. One of the learners said 'In South Africa you are nothing if you are unable to communicate in English because the majority of South Africans speak English and English is a major prerequisite for employment.'

In Library B the library-based programme attracted learners wishing to improve their Afrikaans writing and reading skills for a variety of reasons. They wished to improve their lives, get better jobs, read to their grandchildren and gain their independence. Those in the hospital-based programme wished to improve their Afrikaans reading and writing as 
part of a skills development programme for employees without basic education. Learners expected at the end of the programme to be able to communicate and cope with written materials, to perform their jobs better and to get better jobs. One of them said, 'One day I want to finish my Matric therefore I have to start with the ABET classes in my language (Afrikaans)' while another explained, 'I want to help my grandchildren with their school work and to be able read for them'. They wished to be able to solve their daily problems such as reading instructions, filling out a form, using an ATM and communicating better in order to improve their lives as one of them in Library B said 'Through the classes I will be able to communicate better and to perform my duties better'.

\subsection{The programmes}

The range of offerings across all three programmes was similar: reading, writing, communication (in English at Library $\mathrm{A}$ and in Afrikaans in Library B), numeracy and general life skills. The learners were taught how to read and write their names, their addresses and identity numbers, and how to read timetables, address envelopes and fill out forms. Their learning was based on their daily activities such as reading instructions and product labels, and how to write and address letters. The communication skills module emphasised initiating and maintaining a conversation, voicing opinions, and asking and answering questions. The major difference between the two libraries with respect to delivery of the curriculum was that of language: English in Library A, and Afrikaans in both programmes of Library B. The majority of learners in Level Three viewed the literacy programme as helpful and useful to them because they were able to read and write basic information such as timetables and road.

Learners in the hospital-based programme of Library B were exposed to lessons in critical thinking or the ability to analyse information, reading and responding to advertisements, reading newspapers, and short stories were also included. They were also learning basic employment rights such as leave entitlements, how to select insurance policies, budgeting, bonuses, pension funds and tax related issues. One of the learners in Library B said, Although I know and understand Afrikaans I didn't know how to read and write it. Through these classes I have learned to write and read simple sentences and my biographical information'. The majority of learners in Library B already had jobs but since they were not satisfied with their level of employment and performance they joined literacy classes in order to improve their literacy skills and perform their duties better. Some of the learners in Library B joined literacy classes for social and personal reasons such as the ability to read medication and read to grandchildren. Learners in Library A viewed literacy and English as an economic need. Although they were literate in their home languages they were illiterate in English and they viewed English as a gateway to employment.

The library-based programme of Library B included a life skills course consisting of income generation skills such as fabric painting, decorating candles, making greeting cards and working with beads and candles. All learners in library B enjoyed life skill course because they said it kept them busy and it allowed them to use their creativity. One of them said, 'I like the life skills course because it keeps me busy and its gives me an opportunity to be creative'. Computer skills were offered at Library A which also offered a business course focusing on business writing skills, using banks and basic business concepts. Learners regarded business and life skills courses as important aspects of their classes for functional purposes and for those who wanted to start their businesses.

Different funding models were used at the two libraries. In Library $A$ the programme was funded by the library, and by external sponsors such as the Rotary Club. The facilitators were unpaid volunteers, while those at Library $B$ were paid. Library B received government support from the Department of Education for the library-based programme and from the Department of Health for the hospital-based programme. Both librarians complained that their funding was insufficient, and that they did not receive financial support from their parent organisation. In spite of the departments' subvention of the programmes run by Library $B$, the level of support was inadequate, and could not sustain the minimum requirement of an adequate supply of learning and teaching materials (discussed in 4.3).

\subsection{Learning Materials}

In Library A, the learning materials were written in simple English with pictures and illustrations. They were based on daily issues like doing shopping, going to town, reading road signs, job related issues, writing letters, basic comprehensive skills and health issues. Each level had its own materials. The library provided MediaWorks, produced by an ABET organisation, for their classes, which could be used both as computer-aided and facilitator-mediated instruction. The MediaWorks consists of workbook exercises and facilitators support. Computer aided materials were regarded as very helpful to the learners because they provided basic introduction to computers.

None of the learners in Library B's programmes had any learning materials. Facilitators collected and used different sources such as newspapers, story books, selected lessons from Unit Standards (the official ABET curriculum material) and ad hoc library materials to create their own learning and teaching materials for instruction and for exercises. The facilitators viewed the process of collecting different sources of materials for their learners as time consuming and 
laborious. One of the facilitators complained, 'I ordered an Afrikaans book at our departmental library six months ago but I have not yet received it. It is very difficult and time consuming to collect materials from different books'. The learners unanimously viewed this as a serious obstacle to effective learning in their classes. The Department of Education, in particular, expected learners to be assessed based on Unit Standards while learners did not have such materials. Unit Standards are published by the Department of Education to support their literacy programmes.

Both libraries had post-literacy materials displayed in a special section of the library. These post literacy materials were published by South African publishers such as New Reader's Project, Project Literacy and Kwela Books. They were written in South African languages, with pictures and illustrations. In addition Library A had a special literacy collection housed separately in the Centre where the classes were conducted.

\subsection{The learners' reading tastes and requirements}

The learners at all the centres were asked what kind of materials they liked to use. There was no marked difference in reading requirements and taste. They all expressed a preference for the Bible, magazines, newspapers, love stories, cookery books and business related books, and they all wished to have materials they could relate to, that would assist them with their learning, and to cope with the demands of everyday living. One of the learners in Library B said, 'I like love stories and cookery books that are written in simple language and I also like books with pictures' while one learner in Library A said, 'I like materials that can help me to deal with daily challenges such as health issues and social grants'. They all preferred simple written materials with bright colours, pictures and large fonts.

The learners were asked whether they practised their skills at home. The majority of learners (26 or $74 \%)$ at Library A were practising at home, while the remaining nine (26\%) were not. The reasons cited were lack of materials at home, and the absence of someone to guide and monitor them. Eight out of ten learners in the library-based programme of Library $B$ were practising their skills at home, while the majority at the hospital-based programme were not, due to time constraints.

\subsection{Book ownership}

The majority of Library A learners (29 or $83 \%$ ) owned books or reading materials. These were Bibles (in their home language), magazines and dictionaries. Very few had books in English. The minority (6 or 17\%) did not own books because they did not see the need as they could not read. In the library-based programme of Library B seven out of ten learners owned Bibles, storybooks, high school textbooks, cookery books and biographies. The three who did not said that they saw no need as they could not read, and if they wanted to they could use the library, reasons similar to those advanced by the Library A group. Five of the nine learners at the hospital programme of Library B had books at home with a similar variety to those from the library-based programme: Bibles, cookery books, history books and school textbooks. Those who did not have any books said that there was no point as they could not read. The total book ownership was as follows: 4 I (76\%) learners owned books, while the minority of I3 (24\%) learners did not.

\subsection{Library membership and use}

Low library membership was found across all groups. In Library A, 15 out of 35 learners were members of a library, while in Library B, 4 out of 10 at the library site were members of the host library and 4 out of 9 at the hospital site were members of their local library, not the host library which was too far for them to visit. Thus, a minority of learners across all sites were library members: $42.6 \%$, or 23 out of 54 . There is scope for growth in library membership at Library A where the 20 learners not yet members will receive a library card having completed Level One of their course and progressed sufficiently to complete the membership form. Library membership was used as a motivation for the learners to reach the milestone of being able to complete a form. Those learners at Library B who were not members of the library said that they were unable to read and write and they could not use the library which was a place for literate people and they did not want to disclose their status to the librarians. The learners who were using the library said that the materials they liked to read were available in their local library. They did not use the literacy collection but used newspapers, magazines and children's books.

The respondents were asked about their general use of the library collection even if they did not take out materials. A slim majority of learners at Library A, that is 18 (5l\%), did not use the library collection while the remaining 17 (49\%) did use the library. The majority of the reasons for not using the library were similar to those for not joining the library; they indicated that they were illiterate and therefore unable to use the library. Some of the learners viewed libraries as a place for educated people as the following two representative statements illustrate. 'I don't use the library because I don't want the librarians to know that I am illiterate they will laugh at me' and 'The library is for educated people so I don't belong there'. Their responses were disturbing because they revealed that they had not made the connection between the library as provider of literacy classes, and the library as provider of reading materials to promote literacy through 
voluntary reading. These sentiments do not portray the library as an educational agency hospitable to all irrespective of reading or educational, level.

Some said they were using the learners' literacy collection. Those who were using the library were asked if they were able to get the materials they needed. They all indicated that the materials were available and if they needed something that was not available at the library they used their literacy collection. They also indicated that they did not specifically use the adult literacy materials at the library but they used any materials such as magazines, newspapers and the children's section. None of the 35 learners was a member of a reading club.

Only three learners of the hospital-based programme at Library B were using the library. The remaining learners said that they did not have time to go to the library; that the library was far from their homes and some said the library where they had registered did not have the materials they wanted. They also said that they had requested the materials they wanted from the librarian but they had not had any response. They indicated that they requested simple written adult materials that would help them to practise and maintain their newly acquired skills. There were only three learners who were using the library and they all indicated that their favourite materials were available at the library. They did not specifically use the adult literacy collection but they used a variety of materials such as magazines, newspapers and children's books.

\section{Conclusions and recommendations}

The selected centres provided literacy programmes to equip the adults with basic learning needs and life skills which map to UNESCO's (2005) definition of basic learning needs: 'literacy, oral expression, numeracy, problem solving skills, knowledge, values and attitudes'.

\subsection{Literacy in the lives of the learners}

The learners viewed literacy as an important prerequisite for survival, functionality and participation in a modern society because they all indicated that they wanted to improve their lives in various ways such as the ability to get employment or better jobs or to communicate better, either in their mother tongue, Afrikaans, or in English, the language of commercial sector.

Two cohorts, viz. from Library A and the participants in the hospital programme, were mainly motivated by employment concerns. In the library-based programme of Library B, the learners had more generalised motives for joining the programme: coping with daily needs, some to find employment, and others to be able to read to their grandchildren. The learners who were unemployed (Library A) were very enthusiastic and participative in classes. This programme suffered to a far lesser extent from absenteeism than the programmes offered by Library $B$. The reasons for poor attendance were not clearly identified by learners, facilitators and the librarian at the library-based programme of Library B.

\subsection{The programmes' resources}

Neither of the libraries was satisfied with the level of funding available for the programmes. Inadequate funding for adult education is characteristic of the sector in South Africa and insufficient to meet the needs of literacy training (Rule 2005). Moreover, public libraries have experienced a sustained period of declining funding (Cole 2000) which has led to cuts in service and lack of innovation. Precarious funding was particularly acute in Library B which was unable to purchase any learning materials in spite of the centrality of their role in literacy education. Although there are relevant and suitable literacy materials available for purchase, Library B was not able to avail itself of this due to financial constraints. The availability of literacy materials is a critical requirement for any literacy programme without which there is unlikely to be any change and improvement in the learner's life (Rogers 1994; Cisse 200I; Mabomba 1992; Thomas 1993). The literature shows that the lack of resources in literacy programmes, literacy materials in particular, has an impact on learner motivation, absenteeism and drop out levels. It is recommended that the librarian at Library B and the government departments supporting the programmes should consider the provision of literacy materials as an essential requirement of any literacy programme and take steps to ensure an adequate supply for teaching, learning and voluntary reading.

\subsection{Evaluation of the programmes}

The literacy programmes in both libraries need continuous evaluation because the needs of learners are continuously changing. Through this process the learners and facilitators can be given the chance to identify their needs, expectations and problems and the provider in turn (librarian or other) can specify the objectives of the programmes. Absenteeism and dropout levels need to be monitored and figures to be collected and kept. It is recommended that learners should be motivated in various ways such as the inclusion of income generation programmes that are based on their interests. Such motivation is important for learner participation and retention. 


\subsection{Promotion of the library}

Although learners were encouraged to use the library and their reading materials at home the majority of them (especially those working at the hospital) were reluctant to use the library and to practise their skills at home. It is recommended that the librarians should include library related programmes in literacy programmes for all learners irrespective of their levels. Such programmes can include library visits, story telling, and family literacy offered on a regular basis. Library visits can help the learners to be familiar with the library and be able to speak to the librarians about their needs, thus growing in confidence. Through such programmes the learners can identify their reading needs and the materials they like. Such information can help the librarian to select the materials based on learners' needs. The learners' requests for materials and any information needs need to be followed up by the librarians.

\subsection{Necessary conditions for literacy programmes in the public library}

Factors such as the availability of literacy materials, cooperation and communication between stakeholders and strong commitment from them (stakeholders including the learners) and strong financial support from the government and library's parent bodies are necessary for a fully functioning literacy programme. Through such commitment, libraries will be in a better position to meet the needs of the adults in literacy programmes and so be active partners in nation building and economic and social development.

\section{References}

Aitchison, J. 1999. Literacy and adult basic education and training in South Africa: a quick survey. Adult education and development 53: 99-20.

Aitchison, J. 2006. Decentralisation, management of diversity and curriculum renovation: a study of literacy education in four African countries (Botswana, Kenya, South Africa and Uganda [draft]). [Online]. http://www.adeanet.org/biennial-2006/doc/ document/a3-2Aitchison-en-pdf [10/0I/07].

Arnold, E.R. 1982. The production of suitable reading matter for adult new literates a publisher's viewpoint. Mousaion II. I2: 918.

Baatjes, I. 2003. Reading in South Africa: an overview of policy, programmes and campaigns since 1994. Innovation 26: I-9.

Baatjes, I. and Mathe, K. 2004. Adult basic education and social change in South Africa, 1994 to 2003. In: Changing class: education and social change in post-apartheid South Africa, edited by L. Chisholm. Cape Town: HSRC Press, p. 393-420.

Cisse, S. 200I Post literacy in Mali. [Online]. http://www.iizdvv/de/englisch/publikationen/ewb ausgaben/57 200I/eng cisse.htm. $[10 / 12 / 2006]$.

Cole, J.Y. 2000. Literacy, libraries and IFLA: recent development and a look at the future. [Online]. http://www.ifla.org/IV/ifla66/ papers/02I-139e.html. [10/03/2006].

Foulk, D. et al. 200I. Addressing health literacy: a description of the intersection of functional literacy and health care. American journal of health studies 17 (I) [Online]. http://www.findarticles.com/p/articles/mi m0CTG/is I 17/ai 83662680/print. [12/06/ 06].

French, E. 1992. Adult literacy in South Africa: past to present. In: Adult basic education in South Africa: literacy, English as a second language and numeracy, edited by B. Hutton. Cape Town: Oxford University Press: p. 48-85

Harley A. et al. 1996. A survey of adult basic education in South Africa in the 90s. Cape Town: Sached Books.

Harley, A. 1999. The role of public libraries in Adult Basic Education in South Africa. Mousaion XVII (I): 28-47.

Jordan, P. 2007. Budget speech delivered by Minster of Arts and Culture, Dr P Z Jordan, MP, National Assembly, 8 June 2007. [Online]. http://www.info.gov.za/speeches/2007/0706/2/345/002.htm. [21/06/2007].

Land, S. 2006. Personal interview. 02 November 2006.

Land, S. and Buthelezi, L. 2004. Umkhize, local hero framed: a picture story for beginner adult readers in South Africa. Languages matters. 35 (2): 428-444.

Liu, L.G. 2004. The contribution of public libraries to a country's economy productivity: a path analysis. Library review. 53 (9): 435-44I.

Mabomba, R. 1992. The literate environment in the Southern African context: its creation and sustenance. In: Proceedings of the conference on library and information services for the future development in Southern Africa edited by Coetzer, A.G. Pretoria: Info Africa Nova CC: 32 I-345.

Makhubela, P.L. 1998. Public libraries in the provision of adult basic education programmes: the case of the Western Cape Province, South Africa. Unpublished PhD Thesis. Cape Town: University of Western Cape.

May, B. and Nassimbeni M. 2005. Adult education and literacy in South African public libraries. [Online]. http:// www.centreforthebook.org.za/articles and papers/ABET Report.pdf. [23/02/2006].

Pather, P. 1995. Literacy in South Africa and the role of libraries: an overview. KwaZnaplis. Jul-Aug 3-6.

Reghu, V. [n.d]. Preparation of books for neo-literates in post literacy and continuing education programmes. [Online]. http:// www.literacyonline.org/products/ili/webdocs/reghu.html. [10/04/2005].

R1bn boost for libraries. Report on News24.com. [Online]. http://www.news24.com/News24/South Africa/Politics/0,61/9,27-I2 1878896,00.html. [10/04/2006].

Rogers, A. 1994. Using literacy: a new approach to post literacy materials. Education research series No. 10. [Online]. http:// www.dfid.gov.uk/pubs/files/litpostlitmaterialsedpaper/0.pdf. [20/06/06].

Roman, S.P. 2004. Illiteracy and older adults: individual and societal implications. Educational gerontology 30: 79-93.

Rule, P. 2005. 'The time is burning': the right of adults to basic education in South Africa. [Online]. http:// www.erp.org.za/hmt/abet/doc. [22//0/2006]. 
Sibiya, H.S.2005. A strategy for alleviating illiteracy in South Africa: a historical inquiry. (Unpublished thesis) [Online]. http:// upetd.up.ac.za/thesis/available/etd03 I02005 / 243/3/unrestricted/00front.pdf. [15/03/2006].

Sinha, S.C. 1998. Role of libraries and reading rooms in continuing education. [Online]. http://www.literacyonline.org/products/ili/ webdocs/sinha.html. [16/0I/06].

Sisulu, E. 2004. The culture of reading and the book chain: how do we achieve a quantum leap? [Online]. http:// www.centreforthebook.org.za/events/culture reading.html. [15/04/06].

South African Book Development Council. 2007. Snapshots of the national survey into reading and book reading behaviour of adult South Africans. Pretoria: Department of Arts and Culture.

Tandwa, N. 2007. An investigation into the use of literacy materials by adult learners: a study of the adult education programmes in two Cape Town public libraries. Unpublished M Bibl thesis. Cape Town: University of Cape Town.

Thomas L.C 1993. World literacy and the role of libraries. IFLA journal. 19 (2): I62-169.

Thumbadoo, B. 2006. Making reading matter: guidelines for selecting, developing and disseminating easy readers for adults. Paris: The Association for the Development of Education in Africa (ADEA).

Torres, R.M. 2002. Lifelong learning: a new momentum and a new opportunity for Adult Basic Learning and Education (ABLE) in the South. Adult education and development (Supplement) 60.

Tronbacke, B.I 1997. Easy-to-read: an important part of reading promotion and in fight against illiteracy. IFLA journal 23 (3): I83 $-191$.

UNESCO. 2004. Education: learning programmes for life skills and literacy. [Online]. http://portal.unesco.org/education/en/ ev.phpURL ID 24I49\&URL DO DO PRINTPAGE\&URL SECTION 20I.html. [21/07/06].

UNESCO. 2005. UNESCO global report: education for all monitoring report. [Online]. http://portal.unesco.org/education/en/ ev.phpURL ID 43283\&URL DO DO TOPIC\&URL SECTION 20l.html. [2I/07/06].

Vivian, B. 2002. Evaluating the role of Adult Basic Education and Training (ABET), in terms of fulfilling the need for literacy in English in the private sector. Journal of language teaching. 36 (I\&2): I5-27.

Wagner, DA. 200I. Thematic studies: literacy and adult education. [Online]. http://unesdoc.unesco.org/images/00/2/00/233/ 123333e.pdf. [10/19/2006].

Wedgeworth, R. 2003. The literacy challenge. Conference paper. World Library and Information Congress: 69th IFLA general conference and council I-9 August 2003, Berlin [Online]. http://ifla.sagepub.com. [10/10/2006].

Zapata, M.E. 1994. The role of public libraries in literacy education. Libri 44(2): I23-I 29. 